INSIGHTS INTO REGIONAL DEVELOPMENT

ISSN 2669-0195 (online) http://jssidoi.org/IRD/

2021 Volume 3 Number 1 (March)

http://doi.org/10.9770/IRD.2021.3.1(4)

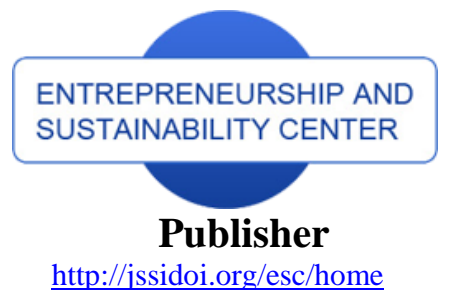

enterprise

europe

network

Business Support on Your Doorstep

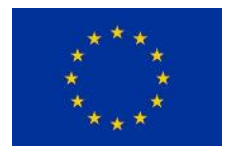

http://jssidoi.org/esc/home

\title{
ISSUES OF STATE AND NATIONAL SECURITY: RELIGIOUSLY INSPIRED TERRORISM IN THE BALTIC STATES INTERNAL AND EXTERNAL FACTORS
}

\author{
Anatolijs Kriviṇš ${ }^{1}$, Jānis Teivāns-Treinovskis ${ }^{2}$, Vladas Tumalavičius ${ }^{3}$ \\ 1,2 Daugavpils University, Vienibas Str. 13, Daugavpils, LV-5401, Latvia \\ ${ }^{3}$ The General Jonas Žemaitis Military Academy of Lithuania, Silo Str. 5A, Vilnius LT-10332, Lithuania \\ ${ }^{3}$ Institute of Humanities and Social Sciences of Daugavpils University, Parades Str. 1, Daugavpils, LV-5401, Latvia \\ E-mails: ${ }^{1}$ anatolijs777@gmail.com ; ${ }^{2}$ janisteivans@inbox.lv; ${ }^{3}$ vladas.tumalavicius@gmail.com
}

Received 15 April 2020; 20 July 2020; published 30 March 2021

\begin{abstract}
Global terrorism has become one of the most serious threats to the security in the world today. The number of suspects arrested for religiously inspired terrorism in the EU Member States increased approximately five-fold between 2009 and 2018. The aim of the paper is to evaluate the threats of Religiously inspired terrorism in the three Baltic States - Estonia, Latvia and Lithuania. The study was conducted using the methods of academic literature, statistical data analysis and qualitative content analysis. This study has applied quantitative technique and qualitative technique to explore the relationship between religiously inspired terrorism and relevant factors Internal factors, Legal migration, Illegal migration, Participation in international missions and operations, Traveling to regions where terrorist groups have a stronger presence, Student exchange programs and foreign students, Employees from other countries e.c. The study has determined that the level of terrorist threats in the Baltics has not changed in recent years and remains relatively low. The Baltic States today is not a target for religiously inspired terrorism. The level of internal threat from existing religious communities has been low and remains low. No significant terrorism-related incidents have occurred in Estonia, Latvia and Lithuania in previous years. There is no reason to believe that these internal risks will increase in the near future. In turn, there are significant long-term risks associated with external threats. A balanced and neutral policy towards all religious denominations should continue in all Baltic countries. As a primary task, the authors conducted an analysis of a number of theoretical and practical tax incentives assessment models.
\end{abstract}

Keywords: national and state security; terrorism; illegal migration; security; religiously inspired terrorism; radicalization

Reference to this paper should be made as follows: Kriviņš, A., Teivāns-Treinovskis, J., Tumalavičius, V. 2021. Issues of state and national security: Religiously inspired terrorism in the Baltic States: internal and external factors. Insights into Regional Development, 3(1), 65-79. http://doi.org/10.9770/IRD.2021.3.1(4)

JEL Classifications: K37, K42

Additional disciplines: law, sociology 
Make your research more visible, join the Twitter account of INSIGHTS INTO REGIONAL DEVELOPMENT:

@IntoInsights

\section{Introduction}

Terrorism has been and remains one of the threats to the security and sustainable development of society since the end of the 20th century. Since the beginning of the 21 st century, the manifestations of terrorism have intensified and take on various forms, including religious ones. The issues of terrorism were raised by many authors in previous studies (Teivāns-Treinovskis, Jefimovs 2012; Kis-Benedek 2016; Besenyő 2016; Avdeev et al. 2017; Beinoravičius, Vainiūtė 2017; Tumalavicius et al. 2017 (a); Tumalavicius et al. 2017 (b); Kordík, Kurilovská, 2017; Roško et al. 2019; Zeman et al. 2018; Beňová et al. 2019; Tvaronavičienè et al., 2020; Masood et al., 2020), but the question of the manifestation of terrorism on the basis of religious beliefs has not been studied much.

In the article, the authors defines terrorism as the use of intentional violence, generally against civilians, for political purposes (Fortna, 2015). Terrorism poses a real and serious threat to people's lives and is a menace for human rights and democracy. States have therefore a duty to protect society against terrorists and to take measures to prevent and punish terrorist activities effectively (Strasbourg, 2018).

Global terrorism has become one of the most serious threats to the security in the world today, endangering the lives of innocent people and society as a whole (MFA, 2019). The Global Terrorism Index (GTI) is a comprehensive study analysing the impact of terrorism for 163 countries and which covers $99.7 \%$ of the world's population (Global Terrorism Index, 2018). According to the GTI 2018, the countries with the highest terrorism index (indicating the highest threat) are: Iraq (9.746), Afghanistan (9.391), Nigeria (8.660), Syria (8.315), Pakistan (8.181), Somalia (8.020), India (7.568), Yemen (7.534), Egypt (7.345), Philippines (7.181), Dem. Rep Congo (7.055), Turkey (7.036), Libya (6.987), South Sudan (6.756), Central African Republic (6.719) (Global Terrorism Index, 2018).

Terrorism, unemployment and the protection of the environment are the three policy areas where, on EU average, more than three-quarters of respondents call for more EU intervention in the future - respectively $77 \%, 76 \%$ and $75 \%$ (Eurobarometer, 2019).

According to GTI data (Global Terrorism Index, 2018), the level of influence of terrorism in Estonia, Latvia and Lithuania is low enough: Latvia - 107th with index 0.458, Estonia 116th with index 0.229; but Lithuania ranked 138th with index 0.

This article evaluates the threats of religiously inspired terrorism in the three Baltic States - Estonia, Latvia and Lithuania. The number of terrorist arrests has grown and rapidly evolved in the European Union in recent years (Table 1). Particularly significant growth is in the religiously inspired terrorism segment. 
INSIGHTS INTO REGIONAL DEVELOPMENT

ISSN 2669-0195 (online) http://jssidoi.org/jesi/

2021 Volume 3 Number 1 (March)

http://doi.org/10.9770/IRD.2021.3.1(4)

Make your research more visible, join the Twitter account of INSIGHTS INTO REGIONAL DEVELOPMENT:

@IntoInsights

Table 1. Terrorist arrests arrests by EU Member

\begin{tabular}{|c|c|c|c|c|c|c|}
\hline $\begin{array}{c}\text { Terrorist arrests } \\
\text { / year }\end{array}$ & $\begin{array}{c}\text { Religiously inspired } \\
\text { terrorism }\end{array}$ & $\begin{array}{c}\text { Ethno- } \\
\text { Nationalist } \\
\text { and separatist } \\
\text { terrorism }\end{array}$ & $\begin{array}{l}\text { Left-wing } \\
\text { and } \\
\text { anarchist } \\
\text { terrorism }\end{array}$ & $\begin{array}{l}\text { Right-Wing } \\
\text { terrorism }\end{array}$ & $\begin{array}{l}\text { Other: Single- } \\
\text { issue terrorism } \\
\text { and Non } \\
\text { specified } \\
\text { terrorism }\end{array}$ & $\begin{array}{c}\text { Terrorist arrests } \\
\text { by EU Member } \\
\text { (Total) }\end{array}$ \\
\hline 2009 & 110 & 413 & 29 & 22 & 13 & 587 \\
\hline 2010 & 179 & 349 & 34 & 1 & 48 & 611 \\
\hline 2011 & 122 & 247 & 42 & 5 & 68 & 484 \\
\hline 2012 & 159 & 257 & 24 & 10 & 87 & 537 \\
\hline 2013 & 216 & 180 & 49 & 3 & 87 & 535 \\
\hline 2014 & 395 & 154 & 54 & 34 & 137 & 774 \\
\hline 2015 & 687 & 168 & 67 & 11 & 144 & 1077 \\
\hline 2016 & 718 & 84 & 31 & 12 & 157 & 1002 \\
\hline 2017 & 705 & 30 & 36 & 20 & 428 & 1219 \\
\hline 2018 & 511 & 30 & 34 & 44 & 437 & 1056 \\
\hline
\end{tabular}

Source: Developed by the authors according to the source Europol.

The number of suspects arrested for religiously inspired / jihadist terrorism in the eu member states increased approximately five-fold between 2009 and 2018: 110 persons in 2009, 179 in 2010, 122 in 2011, 159 in 2012, 216 in 2013, 395 in 2014, 687 in 215, 718 un 2016, 705 in 2017 and 511 persons in 2018 (Europol, 2019).

The diversity of religion and beliefs is woven into the fabric of modern European societies. European countries have highly diverse traditions for and approach to religious diversity as well as the place of religion and nonreligious beliefs in public space (council of Europe, 2016).

There are many different religions in the world and many atheists. In theory, a supporter of any religion can radicalize - adopt of "extremist" ideas that promote and eventually lead to acts of terrorism (Malthaner, 2017).

The reasons of terrorism and other conflicts are similar, but there are different means and ways. Three of them characterize terrorism: 1) intentional usage of violence, 2) directed to civilians or civil objects, 3) in order to achieve the political goals (Beinoravičius, Vainiūtè, 2017).

However, in the 21st century, it has become particularly popular to associate terrorism with Islam. The terrorist attacks in the united states in September 2001 (Smith, Zeigler, 2017), led to an increased fear of radical Islam and suspicion towards people of Arabic descent throughout Europe (Chisholm et al., 2011, 120).

In the European Union, there were many terrorist acts in the 21st century that raised the issue. For instance: in 2005 Danish newpaper published 12 caricatures of Muhammad. The cartoons led to attacks on Danish embassies and the embassies of other Nordic and European countries across the Middle East and nortj Africa. More than 100 people were reported to have been killed in clashes related to the demonstrations (CBC, 2015). In 2011 the offices of the French satirical magazine Charlie Hebdo in Paris have been destroyed in a petrol bomb attack. It comes a day after the publication named the prophet Muhammad as its "Edotor-in-Chief" for its next issue. The cover of 


\section{INSIGHTS INTO REGIONAL DEVELOPMENT}

ISSN 2669-0195 (online) http://jssidoi.org/jesi/

2021 Volume 3 Number 1 (March)

http://doi.org/10.9770/IRD.2021.3.1(4)

Make your research more visible, join the Twitter account of INSIGHTS INTO REGIONAL DEVELOPMENT:

@IntoInsights

the magazine carried a caricature of the prophet making a facetious comment (BBC, 2011). In 2015 the deadly shootings in the Paris offices of Charlie Hebdo, a weekly news paper that caricatured the prophet Muhammad (CBC, 2015), left 12 people dead - including the top editor, prominent cartoonists and police officers (Bilefsky, Baume, 2015). In 2016 an assailant rammed a truck into a crowd celebrating Bastille Day in nice, France.

So, terror incidents lead many westerners to perceive Islam as interently extremists. However, one must agree that small numbers of terrorists make headlines, but they are representative of a complex and diverse religion of 1.6 billion adherents (Kristof, 2015).

European culture has always included Muslim elements, as early as the $8^{\text {th }}$ century (Vaisse, 2008). The exact number of Muslims in Europe is unknown. Many European countries do not ask a person's religion on official forms or in censuses, it has been difficult to obtain accurate estimates (Kent, 2008). As show by statistics (Pew research center, 2011), the number of Muslims in Europe is growing and is projected to crow in the future. However, does this also mean an increase in the terrorist thtreat in the EU and the Baltics?

\section{Methods}

This study has applied quantitative technique and qualitative technique to explore the relationship between religiously inspired terrorism and relevant factors - Internal factors, Legal migration, Illegal migration, Participation in International missions and operations, Traveling to regions where terrorist groups have a stronger presence, Student exchange programs and foreign students, Employees from other countries e.c. For this purpose, data is collected from various sources including online data portals, annual reports and public discourse. Data is collected for the time period of 10 years (2009-2018) with annual observations. The study was conducted using the methods of academic literature, statistical data analysis and qualitative content analysis.

\section{Internal factors}

The Latvian polling agency SKDS has also gathered information regarding the religious affiliation of Latvia over the years. In 2018, $26 \%$ of the population was Orthodox, $20 \%$ identified as Catholic while $17 \%$ was Lutheran, and $3 \%$ were Old Believers. $14 \%$ believed in God without being affiliated to any religion, while $15 \%$ declared himself as atheist. A further 3 proc. belonged to other Christian sects or religions (Kaktins, 2018). If the persons to be married belong to the Evangelical Lutheran, Roman Catholic, Orthodox, Old Believers, Methodist, Baptist, Seventh Day Adventist or believers in Moses (Judaism) denominations and wish to be married by a minister of their denomination who has the relevant permission from the leaders of the denomination, then they shall be married in accordance with the procedures of the denomination concerned (The Civil Law, 1937, 51).

The predominant religion in Lithuania is Christianity, with the largest confession being that of the Catholic Church (about $77.2 \%$ of the population) and smaller groups of Orthodox Christians (4.1\%, Orthodox - Old Believers (0.8 \%), Evangelical Lutherans (0.6\%), Sunni Muslim (0.1\%) (Statistic, 2013). The Lithuanian state recognizes Islam (albeit only in its Sunni Hanafi rite) as one of the nine "traditional" religious communities in Lithuania (Racius, 2012, 171).

The following religions live in Estonia: Lutheran 9.9\%, Orthodox $16.2 \%$, other Christian (including Methodist, Seventh-day Adventist, Roman Catholic, Pentecostal) $2.2 \%$, other $0.9 \%$, none $54.1 \%$, unspecified $16.7 \%$ (Statistic, 2011). The state's attitude towards the various religions is remarkably positive and the legislation concerning religious organisations is very liberal (Vakker, Rohtmets, 2008). 


\section{INSIGHTS INTO REGIONAL DEVELOPMENT}

ISSN 2669-0195 (online) http://jssidoi.org/jesi/

2021 Volume 3 Number 1 (March)

http://doi.org/10.9770/IRD.2021.3.1(4)

Make your research more visible, join the Twitter account of INSIGHTS INTO REGIONAL DEVELOPMENT:

@IntoInsights

It should be borne in mind that the size of Muslim communities and the level of activity of these communities vary across the EU. As far as the Baltic States are concerned.

It should be borne in mind that the size of Muslim communities and the level of activity of these communities vary across the EU. As far as the Baltic states are concerned, Muslims in Latvia, Lithuania and Estonia have lived here for a long time. The arrival of adherents of the Islamic faith to the eastern Baltic rim dates back to the first part of the fourteenth century when thousands of recently Islamized Turkic-speaking Tatars started settling on the territory of the Grand Duchy of Lithuania (Racius, 2012, 171). The medieval Grand Duchy of Lithuania of the Polish-Lithuanian Commonwealth included several Muslim lands in the south. From the second half of the seventeenth century the situation in Lithuania was specific, because the aim of the annihilation of the Christians was not only ascribed to rabbinic Jews, but also to Karaites and Tatars-Muslims (Siauciunaite-Verbickiene, 2008).

The first few Muslims who settled in Estonia came as allies of Ivan IV during the Livonian War in 16th century and the first noteworthy Tatar community appeared in the 18th century (Lepa 2016, 193). A small community of Muslim Tatars was established in Riga in the late nineteenth century (Poljarevic, Svanberg, 2009, p.103).

The Muslim communities in the Baltic States are not large. In 2011 the total Muslim population in Latvia was estimated at about 5000 (Stasulane, Priede 2015, 65) and 1,508 in Estonia (but there is still reason to believe that the real figure is today closer to 4,000) (Lepa, 2016, 195). Currently, only several thousand Lithuanian Tatars remain, making up an estimated 0.1 proc. of the country's population. However, with the restoration of Lithuanian independence, they are experiencing a kind of national revival with evidence to suggest there are several hundred non-Tartar converts to Islam (Racius, 2013).

It should be noted that only converts who convert to Islam under the influence of radical ideas and are ready to prove their allegiance to the new religion by violence can display a security threat. The current discourse on radicalisation, however, is based on a strong association betweenterrorism and Islam, especially fuelled by farright parties and groups. This only causes more fear and mistrust in societies, from which follows all the more racism and segregation, providing again a fertile ground for radicalisation (Gruening, 2018). The great divide is not between faiths. Rather it is between terrorists and moderates, between those who are tolerant and those who "otherize" (Kristof, 2015).

In the contemporary Western climate, counter-terrorism discourse dealing with so-called Islamic extremism appears to be obsessed with trying to understand the motives behind what prompts somebody to turn to terrorism (Sian, 2017). In this respect, the author of the article shares the view that the radicalization of one Muslim shouldn't be viewed as representative of the whole Muslim community (Latvian Public Broadcasting, 2016). There are many individuals with extreme opinions, but only a slight fraction of them ever take measures to perform a terrorist attack (Zeman et al., 2018). In 2017, Latvia's Muslim community mainly engaged n private activities and did not have a direct impact on security. The vast majority of Muslims in Latvia are law abiding, loyal members of society. However, it has identified several members of the community who take an interest in radical interpretation.

So far, Muslim communities in the Baltic States have not promoted violence and the immediate threat of terrorism. However, threats can come from outside. For example, according to National Threat Assesment, radicalization of the Lithuanian Muslim community could be externally induced by representatives of foreign controversial Islamic otganizations and movements exploiting its division and eager to alter local traditions, 


\section{INSIGHTS INTO REGIONAL DEVELOPMENT}

ISSN 2669-0195 (online) http://jssidoi.org/jesi/

2021 Volume 3 Number 1 (March)

http://doi.org/10.9770/IRD.2021.3.1(4)

Make your research more visible, join the Twitter account of INSIGHTS INTO REGIONAL DEVELOPMENT:

@IntoInsights

promote radical interpretation of Islam, attempt to seize the leadership of the Muslim communities and create isolated groups (National Threat Assesment, 2019).

The dialogue between Christian and non-Christian religions is nearly non-existent and there seems to be no will to intensify interrelations. If problems emerge, the representatives of the various religions turn to the state rather than discuss them among themselves (Vakker, Rohtmets, 2008).

Predicting these types of terrorist acts is difficult enough. Members of different social groups, irrespective of gender, age, ethnicity or occupation, may be at risk of radicalization (OSCE, 2014). In this sense, the most important terrorist threat in the Baltic States is the potential radicalization of individuals under the influence of various ideologies justifying violence. In this context the most likely threat continues to be lone individuals or pairs inspired by jihadist ideology (Bergen, Sterman, 2019).

Although the threat from indigenous residents is low, there are several contact points with countries with a terrorist threat. Therefore, the follow-up to the article will look at different groups whose religious radicalization is more likely than existing communities.

\section{Legal migration}

According to Kis-Benedek (2016), the connection between illegal migration and terrorism is in the focal point of security dilemmas since the beginning of the flow of migration. 2015 year saw record-breaking levels of forced migration; over 60 million individuals were pushed from their homes. Neither the refugees nor the better life seeking are terrorists. The refugees look for protection against persecution often perpetrated by terrorists. However it should be taken into consideration that the terrorist organizations can use the illegal migration to send operatives to the target countries.

There's no avoiding the risk that people connected with terrorism may arrive in Latvia, Lithuania or Estonia, but it's a risk that can be dealt with by conducting thorough background checks. If we are dealing with the situation in the EU, we need to pay attention to official statistics. When analyzing migration volumes, observing the national context is key for a correct reading of the results, as European averaged results would hide the manifold nuances in national situations (Eurobarometer, 2019). The Baltic States have been very sensitive to immigration from outside the European Union and stringent about maintaining their ethnic balance, as well as protecting their languages and cultures. The Migrant Integration Policy Index (MIPEX) has continuously noted the antiimmigrant sentiment that exists in all three Baltic countries (Birka, 2019). Under a 2015 EU plan to allocate asylum seekers more equitably across the bloc, Estonia, Latvia, and Lithuania were obliged to accept 1,679 refugees in total. Despite this relatively small number, the issue of refugees has been deeply unpopular in the Baltics, contributing to the governments' sluggish response in meeting quotas and hesitation to pledge to take in more refugees. For example, in 2018 Latvia granted refugee status to just 23 individuals (Birka, 2019).

To prevent them from becoming attached to radical ideologies, it's important to integrate the immigrants into society in a timely and systematical manner. Journalists of the Public media of Latvia followed the results of the pilot project lasting for half a year in Jelgava, where the local government provided support to refugees and persons acquiring the alternative status, providing them with a dwelling. Thus 450 asylum seekers can be currently placed at the same time in the asylum seekers accommodation centre in Mucenieki (Silina-Osmane, 2018). In Estonia, the policy for a new database was worked out that would store all of Estonian residents' fingerprints and possibly other biometric data in order to make document fraud and false identity usage 


\section{INSIGHTS INTO REGIONAL DEVELOPMENT}

ISSN 2669-0195 (online) http://jssidoi.org/jesi/

2021 Volume 3 Number 1 (March)

http://doi.org/10.9770/IRD.2021.3.1(4)

Make your research more visible, join the Twitter account of INSIGHTS INTO REGIONAL DEVELOPMENT:

@IntoInsights

impossible (EMN, 2019). Estonia decided to maintain its immigration quota, which was fulfilled already in January 2019 (EMN, 2019). Finally, refugees who do end up in the Baltics often move on to wealthier EU countries (Birka, 2019).

On the other hand, it must be concluded that asylum seekers from countries at risk or in conflict do not aspire to the Baltic States. The salary disparity between the Baltic countries and Western Europe, as well as the unfavorable popular perception about the economic situation of the countries, makes it highly unlikely that migration will significantly increase (Birka, 2019). The number of migrants residing in Latvia, Lithuania or Estonia, is not significant by Western European standards (Subhan, 1998). The analysis carried out shows that the threat to Baltic security from asylum seekers - both in number and in citizenship - is currently minimal.

However, it must be borne in mind that migration and the perceived threat from Islamisation are key topics on the agenda of right-wing extremists (Europol 2017). In this case, terrorism is directed against migrants and refugees or those supporting them, motivated by racist political ideologies and anger against policies promoting integration or universal access to entitlements (Gruening, 2018).

In 2015, there were some incidents in the Baltic States that affected this topic. 09/03/2015: Assailants set fire to an asylum seekers' center in Vao village, Laane-Viru County, Estonia. No one was injured, but the center was slightly damaged in the blaze. No group claimed responsibility for the incident (Global Terrorism Database, 2019). On September 24, 2015 the Riga municipal police broke up an unsanctioned Muslim outdoor prayer in a Brivibas Street courtyard attended by around 30 men for violating the public statutes on organization of public entertainments and festive events (Krenberga, 2015). On September 27, unknown persons painted islamophobic title in English on a wall of a mosque in Riga. Commenting the incident, representatives of the Latvian Islam Cultural Centre drew attention to increasing level of Islamophobia in Latviaand called mass media to be more careful in the way information regarding Islam is presented (LCHR, 2015).

\section{Illegal migration}

Alongside the problem of official migration, there is the problem of illegal migration, which can significantly increase the risks of terrorism. For example, in Latvia, 104 third-country nationals were detained in 2017 for irregularly crossing the green border (in 2016 - 369; in 2015 - 463, in 2014 - 139; in 2013 - 49; in 2012 - 79, in 2011 - 38; in 2010 - 7, in 2009 - 49; in 2008 - 56 and in 2007 - 17). The key groups of detained persons consisted of the nationals of Vietnam, Bangladesh, India and Iraq.

Both the EU and the Baltic States are contributing to the strengthening of border control. For example, in Bulgaria, a joint operation with neighboring Greece was carried out. In Latvia, a joint project with Lithuania and Estonia was implemented for the development of a common information exchange mechanism (EMN, 2019). The Council of the European Union adopted on 6 December 2018 a common set of operational measures to more effectively target migrant smuggling criminal networks. Furthermore, a Western Balkans task force was set up that included Balkan countries. The Joint Operational Office organised a conference to share good practices for combating smuggling and trafficking in human beings and launched the Internal Security Fund (ISF) supported 'Silk Road' project in 2018, with the goal of combating irregular migration and people smuggling concerning Afghanistan, Iran, Pakistan and Turkey. Further partners in the project were Bulgaria, Hungary and Interpol (European Migration Network, 2019). 


\section{INSIGHTS INTO REGIONAL DEVELOPMENT}

ISSN 2669-0195 (online) http://jssidoi.org/jesi/

2021 Volume 3 Number 1 (March)

http://doi.org/10.9770/IRD.2021.3.1(4)

Make your research more visible, join the Twitter account of INSIGHTS INTO REGIONAL DEVELOPMENT:

@IntoInsights

The EU is taking some steps to regulate migration flows, however as controls tighten over the direct route from Greece into continental Europe, the route through Moldova, Ukraine and into the Baltic may become more popular (Sytas, Mardiste 2016). In any case, however, the Baltic States are not the target, but transit countries for illegal migration.

\section{Participation in international missions and operations}

Estonia, Latvia and Lithuania participate in the EU Civilian and Military Operations, the NATO Military Operations and the Organization for Security and Cooperation in Europe (OSCE). For example, Estonia first began participating in international operations in 1995. Estonia nas participated in the NATO peace support mission in Kosovo (KFOR - Kosovo Forces) since 1999. Estonia began its military involvement in Afghanistan in 2002 in the US-led Operation Enduring Freedom. Since 2003, Estonia participated in the NATO-led International Security Assistance Force (ISAF). Estonian Defence Forces serve in the United Nations MINUSMA mission in Mali since September 2013. Estonian Defence Forces infantry platoon and staff officers serve in UN peacekeeping mission in Lebanon since May 2015. Starting in 2015, Estonia is taking part in the European Union military operation EUNAVFOR MED. Estonian Defence Forces partcipate in the Inherent Resolve operation in Iraq since 2016. Estonian officers have participated as military observers in Middle-East with UNTSO (United Nations Truce Supervision Organisation). Estonian observers are serving in rotations in Israel, Lebanonand Syria. Since 1996, when Latvian soldiers first participated in operation in Bosnia and Hercegovina managed by NATO, Latvia has gor involved in all NATO operations in the Balkans, Iraq and Afganistan (MD, 2019). Thus, Lithuania's contributions to international and NATO operations began in 1994.

This review shows that the Baltic States are actively involved in international operations, including in countries with a large number of terrorists (Iraq, Afghanistan, Syria). Certainly, participation in such missions poses some risks. Several specific incidents can also be mentioned in this context: 11/04/2010 - in Nyala, Janub Darfur, Sudan, eight gunmen kidnapped three Latvian helicopter crew members in a Nyala neighborhood. The two pilots and one mechanic were working for the World Food Program and were taken to an unknown location by motor vehicle. No casualties were reported and the hostages were released unharmed on 12/08/2010 in an unknown area of Sudan. No group claimed responsibility for the attack (Global Terrorism Database, 2019).

01/24/2012 - An explosive device detonated, targeting a patrol of soldiers taking part in a North Atlantic Treaty Organization (NATO) operation in Nad Ali district, Helmand province, Afghanistan. An Estonian soldier was injured in the attack. No group claimed responsibility for the incident. 05/03/2012 - An explosive device detonated next to a North Atlantic Treaty Organization (NATO) Special Operations Squadron in southern Afghanistan. Three Lithuanian soldiers were injured in the blast. No group claimed responsibility for the attack. 09/19/2013 - Assailants fired on a European Union Rule of Law Mission in Kosovo (EULEX) convoy near Zvecan village, Kosovska Mitrovica district, Kosovo. One EULEX officer from Lithuania was killed in the assault. No group claimed responsibility for the attack. 11/18/2018 - Assailants fired missiles at a North Atlantic Treaty Organization (NATO) base housing Lithuanian forces in Kandahar, Afghanistan. No casualties were reported in the attack. No group claimed responsibility for the incident (Global Terrorism Database, 2019).

Theoretically, participation in international missions could increase the risk of terrorist acts on the territory of the Baltic states, as retaliation by terrorist organizations (such as the Madris bombings of 11 March 2004). However, such risks can be assessed as sufficiently low for a number of reasons. First of all, the military presence of the Baltic States, and thus the influence on the course of events, is not large in international missions; secondly, they do not form missions in the Baltic States, but join them. Third, terrorist's acts are a complex and labor-intensive 
INSIGHTS INTO REGIONAL DEVELOPMENT

ISSN 2669-0195 (online) http://jssidoi.org/jesi/

2021 Volume 3 Number 1 (March)

http://doi.org/10.9770/IRD.2021.3.1(4)

Make your research more visible, join the Twitter account of INSIGHTS INTO REGIONAL DEVELOPMENT:

@IntoInsights

process, but the Baltic territory is neither a European political nor an economic center where terrorists can achieve a particular terrorist effect. No matter how attractive it may seem, the Baltic States should not exclude themselves from international processes, because only by providing a helping hand to other nations can they count on the support of other countries, if necessary.

\section{Traveling to regions where terrorist groups have a stronger presence.}

Another key factor in radicalization is traveling to regions where terrorist groups have a stronger presence. Analysis of terrorist trends indicates that traveling to regions where terrorist groups have a stronger presence can facilitate people's exposure to the violent ideology preached by terrorist groups and the establishment of contacts with terrorists. Upon their return, they may adversely affect the security interests of the Baltic.

The number of Europeans travelling as foreign terrorist fighters (FTFs) to the conflict areas in Syria and Iraq, the intensive use of the internet and social media in propaganda and recruitment activities, and the terrorist attacks in EU Member States directed or inspired by terrorist organisations, have caused a major increase in the number of cases at Europol concerning "crimes committed or likely to be committed in the course of terrorist activities against life, limb, personal freedom or property" - a development that is not expected to come to a halt soon (Eurobarometer, 2019). Considering the seriousness of the threat and the need, in particular, to stem the flow of foreign terrorist fighters, it is necessary to criminalise outbound travelling for the purpose of terrorism, namely not only the commission of terrorist offences and providing or receiving training but also the participation in the activities of a terrorist group (Directive, 2017). EU Member States may also decide to address terrorist threats arising from travel for the purpose of terrorism to the Member State concerned by criminalising preparatory acts, which may include planning or conspiracy, with a view to committing or contributing to a terrorist offence (Directive, 2017).

\section{Student exchange programs and foreign students}

International students constitute a group of migrants that does not provoke resistance in receiving societies and are generally viewed positively. States compete to attract the brightest students, create favorable conditions for their arrival and stay (IOM, 2012). Yet despite the importance of this topic, this specific group of migrants (IOM, 2012) was not properly researched from the terrorist threat perspective. It should be noted that extremists are also very active in and around universities, where they can find opportunities for recruitment (Europol, 2017). The British government has identified universities as a key site for recruitment by extremist organizations (Choudhury, 2017).

The numbers of internationally mobile students are increasing (MDP, 2018). There were at least 1.6 million students from abroad who were undertaking tertiary level studies across the EU in 2016 (Eurostat, 2018). In the academic year 2018/2019, there are 80,400 people studying at Latvia's universities of colleges as compared to 81,600 students in the previous academic year. At the same time, the number of mobile students (those who acquired previous education abroad) has continued to growing significantly. There are currently 8,400 mobile students in Latvia, which is $11.7 \%$ more than last year and $60.8 \%$ more than in 2014 when such statistics was compiled for the first time (Balticcourse, 2019). For example, the number of foreign students at Riga Technical University has grown substantially over the past few years, rising to over eight years - there are students from 80 different countries including Uzbekistan, Kazakhstan, Mauritius, Thailand, Bhutan and Vietnam (RTU, 2018). 


\section{INSIGHTS INTO REGIONAL DEVELOPMENT}

ISSN 2669-0195 (online) http://jssidoi.org/jesi/

2021 Volume 3 Number 1 (March)

http://doi.org/10.9770/IRD.2021.3.1(4)

Make your research more visible, join the Twitter account of INSIGHTS INTO REGIONAL DEVELOPMENT:

@IntoInsights

2018 saw a noticeable rise in the number of international students who started their studies in Estonia - the increase for international admission was nearly $25 \%$ (Piliste, 2019).

There are around 5000 foreign students (both - from EU and non EU nationals) studying in Estonia (840 in 2005; 901 in 2006; 885 in 2007; 908 in 2008; 1027 in 2009; 1282 in 2010; 1573 in 2011; 1876 in 2012; 2230 in 2013; 2887 in 2014; 3476 in 2015; 3917 in 2016; 4395 in 2017 and 5047 in 2018). Top 10 countries of foreign degree students in Estonia are follows: Finland, Russia, Nigeria, Ukraine, Turkey, India, Bangladesh, Georgia, USA, Latvia (Piliste, 2019).

According report of Education Monitoring and Analysis Centre, between 2013 and 2017, the number of foreign students enrolling in higher education institutions in Lithuania increased by $15 \%$ In total 10246 foreign students enrolled in higher education institutions in 6 years. (EMAC, 2018). In 2019 Vilnius Gediminas Technical University welcomed new full-time degree seeking international students from 58 countries, including Egypt, Ecuador, the United Arab Emirates and Kazakhstan (Studyin, 2019).

The above data show that students from countries at risk of terrorism are also studying at universities and colleges in the Baltic States: (Iraq, Nigeria, Syria, Pakistan, India, Egypt, Philippines, Turkey, Libya). The number of such students is sufficiently large. For example, in Latvia, during the 2018/2019 academic year 2070 students from India ( $24.7 \%$ of the total number of mobile students) studied.

According Mol and Ekamper (2016), students from Southern Europe seem to mainly move within their own region, as well as towards Eastern Europe. This pattern might be related to similarities between localities in terms of costs of living, culture and/or climate. Students from the Baltic States also study in different regions of the world. Analyzing the countries with which the Baltic States implement goping student exchange programs, it can be concluded that it does not present a real and significant terrorist threat. However, particular attention should be paid to Turkey, which may be considered a country with a significant presence of terrorist groups and is a potential point of contact with extremists. Exchange programs with Turkey are sufficiently intensive. Analysis of the trends in terrorism suggests that long-term residence in these regions could theoretically lead to a radical interpretation of Islam or even to building contacts with terrorist groups there. This, in turn, could adversely affect the security interests of the Baltic upon their return.

\section{Employees from other countries}

The number of foreign nationals, who reside permanently and have been employed in the country, has increased by 18 percent in Lithuania in five years, from 12.7 thousand (in 2014) to 15 thousand (in 2018). Whereof, about 6.8 thousand were hired in Lithuania both in 2014 and 2018 (GSAC, 2019). In 2018, the total number of foreign nationals employed in Lithuania was about 57 thousand, mostly foreigners on a temporary basis (42 thousand). Another part (15 thousand) consisted of foreigners who permanently reside in Lithuania.

Number of foreigners working in Latvia grows steadily. However, data say people from more exotic countries such as India, the Philippines and China have also received work permits. By 2014 a total 5,502 work permits had been issued to foreign nationals. The figure grew to 6,165 in 2015 and 7,590 in 2016. By January 1, 2017 a total 8,625 permits were active with 3,875 issued to non-EU nationals. The number of issued work permits has grown by 56 proc. within four years (Pelane, 2017). Number of foreign specialists in Estonia continues to increase. For instance, in 2018 there was a total of 2794 temporary residence permits for employment given to non-EU 


\section{INSIGHTS INTO REGIONAL DEVELOPMENT}

ISSN 2669-0195 (online) http://jssidoi.org/jesi/

2021 Volume 3 Number 1 (March)

http://doi.org/10.9770/IRD.2021.3.1(4)

Make your research more visible, join the Twitter account of INSIGHTS INTO REGIONAL DEVELOPMENT:

@IntoInsights

nationals, which is an increase big increase compared to 2017 (Work Estonia, 2019): 863 in 2013; 1237 in 2014 ; 1659 in 2015; 1800 in 2016; 2272 in 2017 and 2749 in 2018.

In theory, foreign workers can also contribute to the risks of religious terrorism. In practice, however, the exercise of this option is complicated by lengthy bureaucratic procedures. In the past ten years, there have been no cases in the Baltic involving Employees from other countries engaging in religious terrorism.

\section{Conclusions}

The level of terrorist threats in the Baltics has not changed in recent years and remains relatively low. While the European Union has seen a series of attacks by individuals and groups inspired by jihadism, the Baltic States today is not a target for religiously inspired terrorism. No significant terrorism-related incidents have occurred in Estonia, Latvia and Lithuania in previous years. The level of internal threat from existing religious communities has been low and remains low. There is no reason to believe that these internal risks will increase in the near future.

In turn, there are significant long-term risks associated with external threats. In the Baltic States, the focus should be on terrorist threat offenses, such as attack directed from abroad: legal migration and illegal migration, participation in international missions and operations, traveling to regions where terrorist groups have a stronger presence, student exchange programs and foreign students and employees from other countries.

There are currently no persons, groups or organizations using terrorist methods in the context of religious ideas in the Baltic countries. However, all of these groups are more exposed than the rest of the population to the risk of radicalization, which could be facilitated both by their potential contacts in terrorist-threatened countries and by terrorist propaganda on the Internet. The threat of religiously motivated terrorism, both in the Baltics and around the world, is not linked to religion as such, but to the individual's understanding of the religion, worldview and psychology involved in terrorist activities. No religion can be dangerous in itself unless its adherents call for violence or commit violence, seeking religious support to justify their terrorist activities. A balanced and neutral policy towards all religious denominations should continue in all Baltic countries.

\section{References}

Annual Report on Migration and Asylum 2018 (2019). European Migration Network. Available at: https://ec.europa.eu/homeaffairs/sites/homeaffairs/files/00 arm2018 synthesis report final en.pdf

Avdeev, V., Avdeeva, O., Rozenko, S., Znamerovskiy, E., Kiselyov, E. (2017). Crime of the Terrorist Character and Extremist Orientation in the Russian Federation: State and Measures of Counteraction. Journal of Security and Sustainability Issues, 7(2), 359-367. https://doi.org/10.9770/jssi.2017.7.2(15)

Beinoravičius, D., Vainiute, M. (2017). The management of terrorism roots as a prerequisite for successful fight against terrorism. Journal of Security and Sustainability Issues, 7 (2), 13-22. https://doi.org/10.9770/jssi.2017.7.2(2)

Beňová, P., Hošková-Mayerová, Š., Navrátil, J. (2019). Terrorist attacks on selected soft targets, Journal of Security and Sustainability Issues 8(3): 453-471. https://doi.org/10.9770/jssi.2019.8.3(13)

Bergen, P., Sterman, D. (2019). Terrorism in America After 9/11. New America. Available at: https://www.newamerica.org/indepth/terrorism-in-america/what-threat-united-states-today/

Besenyő, J. (2016). Security preconditions: understanding migratory routes. Journal of Security and Sustainability Issues, 6(1), 5-26. https://doi.org/10.9770/jssi.2016.6.1(1) 


\section{INSIGHTS INTO REGIONAL DEVELOPMENT}

ISSN 2669-0195 (online) http://jssidoi.org/jesi/

2021 Volume 3 Number 1 (March)

http://doi.org/10.9770/IRD.2021.3.1(4)

Make your research more visible, join the Twitter account of INSIGHTS INTO REGIONAL DEVELOPMENT:

@IntoInsights

Bilefsky, D., Baume, M. (2015). Terrorists Strike Charlie Hebdo Newspaper in Paris, Leaving 12 Dead. The New York Times, 07.01.2015. Available at: https://www.nytimes.com/2015/01/08/world/europe/charlie-hebdo-paris-shooting.html

Birka, I. (2019). Can Return Migration Revitalize the Baltics? Estonia, Latvia, and Lithuania Engage Their Diasporas, with Mixed Results. Migration Policy Institute. 08.05.2019. Available at: https://www.migrationpolicy.org/article/can-return-migration-revitalize-balticsestonia-latvia-and-lithuania-engage-their-diasporas

Charlie Hebdo Paris shooting: How criticisms, satires of Islam have sparked violence (2015). CBC. 07.01.2015. Available at: https://www.cbc.ca/news/world/charlie-hebdo-paris-shooting-how-criticisms-satires-of-islam-have-sparked-violence-1.2892571

Chisholm, L., Kovacheva, S., Merico, M. (2011). European youth studies. Integrating research, policy and practice. Available at: https://pip-eu.coe.int/documents/42128013/47261653/maeys_2012.pdf/38e80a55-bbe2-40fc-b9f7-dd1eb7352a72

Choudhury, T. (2017). Campaigning on campus: Student islamic societies and counterterrorism. Studies in Conflict and Terrorism, 40(12), 1004-1022. Available at: https://doi.org/10.1080/1057610X.2016.1253986

Directive (EU) 2017/541 of the European Parliament and of the Council of 15 March 2017 on combating terrorism and replacing Council Framework Decision 2002/475/JHA and amending Council Decision 2005/671/JHA. Available at: https://eur-lex.europa.eu/legalcontent/EN/TXT/?uri=CELEX\%3A32017L0541

Education Monitoring and Analysis Centre (2018) Report. Available at: https://www.registrucentras.lt/jar/paieska/

Ethnicity, mother tongue and religion (2013). Official Statistics Portal. Available at: https://osp.stat.gov.lt/en/web/guest/informaciniaipranesimai articleId $=223122$

EU Terrorism situation and Trend report (2015). Europol. Available at: https://www.europol.europa.eu/activities-services/mainreports/european-union-terrorism-situation-and-trend-report-2015

EU Terrorism situation and Trend report (2017). Europol. Available at: https://www.europol.europa.eu/activities-services/main-reports/euterrorism-situation-and-trend-report-te-sat-2017

EU Terrorism situation and Trend report (2019). Europol. Available at: https://www.europol.europa.eu/activities-services/mainreports/terrorism-situation-and-trend-report-2019-te-sat

European Parliament Eurobarometer EB89.2 (2019). Available at: https://www.europarl.europa.eu/at-your-service/files/beheard/eurobarometer/2018/delivering_on_europe_citizens_views_on_current_and_future_eu_action/executive-summary.pdf

Exchange on the religious dimension of intercultural dialogue. The role of education in the prevention of radicalisation leading to terrorism and violent extremism. (2016). Council of Europe. Available at: https://www.coe.int/en/web/ingo/-/the-role-of-education-in-the-preventionof-radicalisation

Former Muslim leader investigated by Security Police (2016). Latvian Public Broadcasting. 01.03.2016. Available at: https://eng.lsm.lv/article/society/society/former-muslim-leader-investigated-by-security-police.a171580/

Fortna, V. (2015). Do Terrorists Win? Rebels' Use of Terrorism and Civil War Outcomes. International Organization, 69(3), 519-556. Available at: https://doi.org/10.1017/S0020818315000089

Global Terrorism Database (2019). Available at: https://www.start.umd.edu/gtd/search/Results.aspx?search=\&sa.x=54\&sa.y=3

Global Terrorism Index 2018. Measuring the impact of terrorism (2019). Institute for Economics \& Peace. Available at: http://visionofhumanity.org/app/uploads/2018/12/Global-Terrorism-Index-2018-1.pdf

Gruening, E. (2018). Prevention of radicalisation through intercultural policies. Policy Brief. Available at: https://rm.coe.int/policy-briefprevention-of-radicalisation-through-intercultural-polici/1680907512

International students (2018). Migration Data Portal (MDP). Available at: https://migrationdataportal.org/themes/international-students

Kaktiņš, A. (2018). Latvijas iedzīvotāju reliǵiskās un konfesionālās piederības (Religious and denominational affiliations of the Latvian population). SKDS, 24.09.2018. Available at: https://twitter.com/ArnisKaktins/status/1044214761557282816

Kent, M. (2008) Do Muslims have more children than other women in Western Europe? PRB, 27.02.2008. Available at: https://www.prb.org/muslimsineurope/

Kis-Benedek, J. (2016). Illegal migration and terrorism. Journal of Security and Sustainability Issues, 5(4), 455-464. http://dx.doi.org/10.9770/jssi.2016.5.4(1) 


\section{INSIGHTS INTO REGIONAL DEVELOPMENT}

ISSN 2669-0195 (online) http://jssidoi.org/jesi/

2021 Volume 3 Number 1 (March)

http://doi.org/10.9770/IRD.2021.3.1(4)

Make your research more visible, join the Twitter account of INSIGHTS INTO REGIONAL DEVELOPMENT:

@IntoInsights

Kordík, M., Kurilovská, L. (2017). Protection of the national financial system from the money laundering and terrorism financing. Entrepreneurship and Sustainability Issues, 5(2), 243-262. http://doi.org/10.9770/jesi.2017.5.2(7)

Krenberga, O. (2015). Riga Muslims face fine for prayers without a permit. Latvian Public Broadcasting, 25.09.2015. Available at: https://eng.lsm.lv/article/society/society/riga-muslims-face-fine-for-prayers-without-a-permit.a147308/

Kristof, N. (2015). Is Islam to Blame for the Shooting at Charlie Hebdo in Paris? 07.01.2015. Available at: https://www.nytimes.com/2015/01/08/opinion/nicholas-kristof-lessons-from-the-charlie-hebdo-shooting-in-paris.html

Latvia and NATO (2019). The Ministry of Defence. Available at: https://www.mod.gov.lv/en/node/306/latvia-and-nato

Learning mobility statistics (2018). Eurostat. Available at: https://ec.europa.eu/eurostat/statistics-

explained/index.php/Learning_mobility_statistics

Lepa, E. (2016) Dynamics of Estonian Muslim community: Earlier developments and current situation. Usuteaduslik Ajakiri, 70(2), 74-91.

Malthaner, S. (2017). Radicalization: The Evolution of an Analytical Paradigm. Archives Europeennes de Sociologie, 58(3), 369-401. Available at: https://doi.org/10.1017/S0003975617000182

Masood, O., Javaria, K., Petrenko, Y. (2020). Terrorism activities influence on financial stock markets: an empirical evidence from United Kingdom, India, France, Pakistan, Spain and America. Insights into Regional Development, $2(1)$, $443-455$. https://doi.org/10.9770/IRD.2020.2.1(4)

Mol, C., Ekamper, P. (2016). Destination cities of European exchange students. Geografisk Tidsskrift - Danish Journal of Geography, 116 (1), 85-91. https://www.tandfonline.com/doi/full/10.1080/00167223.2015.1136229

National Threat Assesment (2019). State Security Department of the Republic of Lithuania and Second Investigation Department under the Ministry of National Defence. Available at: https://www.vsd.lt/wp-content/uploads/2019/02/2019-Gresmes-internetui-EN.pdf

Number of students at Latvia's higher education institutions down 1.5\% (2019). The Baltic Course. 24.01.2019. Available at: http://www.baltic-course.com/eng/education/?doc=146773

Pelane, A. (2017). Number of foreigners working in Latvia grows steadily. Available at:

https://eng.lsm.lv/article/economy/economy/number-of-foreigners-working-in-latvia-grows-steadily.a230436/

Piliste, K. International students in Estonia in 2018/2019. Available at: http://archimedes.ee/en/blog/

Poljarevic, E., Svanberg, I. (2009). Islam in the Nordic and Baltic Countries / Islam in Latvia. Routledge.

Population by County, Age group, Religion, Sex and Ethnic nationality (2011). Statistic. Available at: http://pub.stat.ee/pxweb.2001/Dialog/Saveshow.asp

Preventing Terrorism and Countering Violent Extremism and Radicalization that Lead to Terrorism: A Community-Policing Approach (2014). Organization for Security and Co-operation in Europe. Available at: https://www.osce.org/secretariat/111438?download=true

Racius, E. (2012). Religious Diversity in Post-Soviet Society: Ethnographies of Catholic Hegemony and the New Pluralism in Lithuania / Muslims in Catholic Lithuania: Divergent Strategies in Dealing with the Marginality Status. Routledge, London.

Racius, E. (2013). Lithuanian Muslims’ Attitudes Toward Participation in the Democratic Political Process. Muslim Political Participation in Europe. Edited by J. S. Nielsen. Edinburgh, Edinburgh University Press, 83-101.

Recruitment of foreign specialists most likely to increase in 2019 despite immigration quota limits (2019). Available at: https://www.workinestonia.com/recruitment-of-foreign-specialists-most-likely-to-increase-in-2019-despite-immigration-quota-limits/

Roško, M., Musladin, M., Kazanský, R. (2019). Counter-terrorism in the United Kingdom: sustainable measure or violation of human rights. Journal of Security and Sustainability Issues, 9(2), 603-615. https://doi.org/10.9770/jssi.2019.9.2(19)

Sian, K. (2017). Born radicals? Prevent, positivism, and 'race-thinking'. Palgrave Communications, 3(1), 9. https://doi.org/10.1057/s41599$\underline{017-0009-0}$

Šiaučiūnaitè-Verbickienè, J. (2008). Blood libel in a multi-confessional society: the case of the grand duchy of Lithuania. East European Jewish affairs, 38(2), 201-209. https://doi.org/10.1080/13501670802184082 
INSIGHTS INTO REGIONAL DEVELOPMENT

ISSN 2669-0195 (online) http://jssidoi.org/jesi/

2021 Volume 3 Number 1 (March)

http://doi.org/10.9770/IRD.2021.3.1(4)

Make your research more visible, join the Twitter account of INSIGHTS INTO REGIONAL DEVELOPMENT:

@IntoInsights

Silina-Osmane, I. (2018). Report on Migration and asylum in Latvia. Reference year 2017. Available at: https://ec.europa.eu/homeaffairs/sites/homeaffairs/files/16a_latvia_arm_part2_2017_en.pdf

Smith, M., Zeigler, S.M. (2017). Terrorism before and after 9/11 - A more dangerous world? Research and Politics, 4(4). https://journals.sagepub.com/doi/pdf/10.1177/2053168017739757

Stasulane, A., Priede, J. (2015). Politcal and civic narratve: Factors determining the politcal partcipaton of Muslim Youth in Latvia. Religiski-Filozofiski Raksti, 18, 62-86.

Subhan A. (1998). Migration and Asylum in Central and Eastern Europe. The European Parliament. Directorate General for research. Available at: http://www.europarl.europa.eu/workingpapers/libe/pdf/104_en.pdf

Sytas, A., Mardiste, D. (2016) Worried over refugees, Baltics begin to erect border fences. Reuters. 08.03.2016. Available at: https://www.reuters.com/article/us-europe-migrants-baltics/worried-over-refugees-baltics-begin-to-erect-border-fences-idUSKCN0WA1JN

Teivāns-Treinovskis, J., Jefimovs, N. (2012). State national security: aspect of recorded crime. Journal of Security and Sustainability Issues, 2(2)), 41-48. http://dx.doi.org/10.9770/jssi.2012.2.2(4)

The Civil Law: law of Republic of Latvia (1937). Available at: https://likumi.lv/ta/en/en/id/225418-the-civil-law

The Future of the Global Muslim Population: Projections for 2010-2030. (2011). Pew Research Center. Available at: https://www.pewresearch.org/wp-content/uploads/sites/7/2011/01/FutureGlobalMuslimPopulation-WebPDF-Feb10.pdf

The number of foreign employee Lithuania is increasing (2019). Government strategic analysis center. Available at: https://strata.gov.lt/en/component/content/article/29-news/599-number-of-foreign-employee-lithuania-is-increasing

This Year a Record High Number of Foreign Students Enrolled at RTU (2018). RTU. Available at: https://www.rtu.lv/en/university/formass-media/news/open/this-year-a-record-high-number-of-foreign-students-enrolled-at-rtu

Tumalavičius, V., Nikolayevskyy, V., Endziņš, A. (2017). Issues of the State and Society Security (Part II): Management of Control over Individual Criminal Processes. Journal of Security and Sustainability Issues, 6(4), 605-618. http://doi.org/10.9770/jssi.2017.6.4(6)

Tumalavičius, V., Veikša, I., Načisčionis, J., Zahars, V., Draskovic, V. (2017). Issues of the State and Society Security (Part I): Ensuring Public Security in the Fight against Crime. Journal of Security and Sustainability Issues, 6(3), 401-418. http://dx.doi.org/10.9770/jssi.2017.6.3(7)

Tvaronavičienè, M., Plèta, T., Della Casa, S., Latvys, J. (2020). Cyber security management of critical energy infrastructure in national cybersecurity strategies: cases of USA, UK, France, Estonia and Lithuania. Insights into Regional Development, 2(4), 802-813. http://doi.org/10.9770/IRD.2020.2.4(6)

Unknown persons painted Islamophobic title on a wall of a mosque in Riga (2015). The Latvian Centre for Human Rights, 30.09.2015. Available at: http://cilvektiesibas.org.lv/en/monitoring/search/?page=17\&date=

Vaisse, J. (2008) Muslims in Europe: A Short Introduction. Brookings. 08.09.2008. Available at:

https://www.brookings.edu/research/muslims-in-europe-a-short-introduction/

Vakker, T., Rohtmets, P. (2008). Estonia: Relations between Christian and Non-Christian Religious Organisations and the State of Religious Freedom. Religion, State and Society, 36(1), 45-53. https://doi.org/10.1080/09637490701809712

Zeman, T., Břeň, J. Urban, R. (2018) Profile of a Lone Wolf Terrorist: A Crisis Management Perspective. Journal of Security and Sustainability Issues, (8), 5-18. https://doi.org/10.9770/jssi.2018.8.1(1) 
INSIGHTS INTO REGIONAL DEVELOPMENT

ISSN 2669-0195 (online) http://jssidoi.org/jesi/

2021 Volume 3 Number 1 (March)

http://doi.org/10.9770/IRD.2021.3.1(4)

Make your research more visible, join the Twitter account of INSIGHTS INTO REGIONAL DEVELOPMENT:

@IntoInsights

Anatolijs KRIVIN̦Š, Dr. iur., Asoc. Prof. at the Daugavpils University. Research interests: criminology, terrorism, corruption, criminal justice.

ORCID ID: https://orcid.org/0000-0003-1764-4091

Jānis TEIVĀNS-TREINOVSKIS, Dr., jur., Dean at Daugavpils University. Research interests: criminology, terrorism, corruption, criminal justice.

ORCID ID: https://orcid.org/

Vladas TUMALAVIČIUS, Ph.D. at The General Jonas Žemaitis Military Academy of Lithuania; researcher at the Institute of Humanities and Social Sciences of Daugavpils University, Latvia. He has the status of Expert of the Latvian Council of Science in the fields of Law and of Economics and Entrepreneurship; Expert of the Foundation for Polish Science under Measure 4.4 of the Smart Growth Operational Programme 2014-2020 and Expert of Polish National Agency for Academic Exchange. Research interests: Legal Regulation of Public Safety and Administration; Issues of National, State and Regional Security and Sustainability.

ORCID ID: https://orcid.org/0000-0002-0811-0074

Copyright (C) 2021 by author(s) and VsI Entrepreneurship and Sustainability Center

This work is licensed under the Creative Commons Attribution International License (CC BY).

http://creativecommons.org/licenses/by/4.0/

(c) (i) Open Access 